\title{
Environmental Crude Oil Pollution and its Rising Levels of Socioeconomic/Health Vulnerabilities among the Rural People in Rivers State, Nigeria
}

\author{
Oriji, Christian Chigozi* \\ Department of Sociology, Faculty of Social Sciences, University of Port Harcourt, P.M.B. 5323, Port Harcourt, \\ Choba, Rivers State, Nigeria
}

*Corresponding Author: Oriji, Christian Chigozi, Department of Sociology, Faculty of Social Sciences, University of Port Harcourt, P.M.B. 5323, Port Harcourt, Choba, Rivers State, Nigeria

\begin{abstract}
The main focus of this study was to investigate Environmental Crude Oil Pollution and its Rising Levels of Socioeconomic/Health Vulnerabilities Among the Rural People in Rivers State, Nigeria. Two null hypotheses were generated to guide the study. Survey design was adopted for the study. The population of the study was Rivers State, and it covered all rural people in the state. A sample of 300 rural respondents was selected for the study. The selection was done through the use of simple random sampling and accidental sampling techniques. The questionnaire was the instrument used for data collection. The instrument was face validated by professionals in the Department of Sociology, University of Port Harcourt, Choba. Furthermore, the reliability value of 0.82 Correlation Co-efficient was obtained for the study. The statistical methods used for the study were percentage, a frequency table and a bar-graph as well as chi-square $\left(\chi^{2}\right)$. Percentage was used to analyse biographical data of respondents' results as presented in a frequency table and a bar-graph for the study. In addition, $\chi^{2}$ was used to analyse the tested hypotheses for the study at 0.05 level of significance. The results of the analysis revealed that correlationships (associations) exist between environmental crude oil pollution and its rising levels of socio-economic/health vulnerabilities among the rural people in Rivers State of Nigeria. In congruence with these findings, the study recommended among others that the federal government in conjunction with the state government should ensure that they work with multinational companies to cleanup crude oil spills in the rural areas of the state based on the international best practices, alongside adhere to the domesticated crude oil pollution laws in Nigeria.
\end{abstract}

Keywords: Environmental Crude Oil Pollution, Levels, Socioeconomic, Health, Vulnerabilities, Rural People, Rivers State, Nigeria

\section{INTRODUCTION}

Crude oil pollution can be referred to as oil spill pollution which adversely affects land, air and water environments, the world over. Drawing from this fact, Environmental Pollution Centres (EPC) (2017:1) stipulates that:

Oil spill pollution refers to the negative polluting effects that oil spills have on the environments and living organisms, including humans, due to the environmental discharge of various organic compounds that make up crude oil and oil distillate products, the majority of which include various individual hydrocarbons. Hydrocarbons are made exclusively from carbon and hydrogen atoms which bind together in various ways, resulting in paraffins (isoalkanes) aromatic (such as benzene or various polycyclic aromatic hydrocarbons (PAHs), alkanes (alkenes and alkynes). Other individual compounds that are present in crude oil and oil discharges include (apart from carbon and hydrogen) sulfur, nitrogen and/or oxygen atoms.

In the circumstances of the foregoing, most crude oil producing countries in the developing countries, the world over, suffer from the negative effects of crude oil exploration and exploitation in human environment. Unfortunately, this is the situation in Nigeria; hence the country is currently making efforts to come out of "the maze of crude oil devastating effects on the socioeconomic development and health of people in the oil rich areas of Niger Delta region. Today, the crude oil pollution has also resulted in the reduction of the quantity and quality of food availability to households in the impacted 
communities in Nigeria (Ordinioha and Brisibe, 2013). Worse still, crude oil pollution produces environmental hazards that are "slow poisons", in that they often take months and years to cause disease and death (World Health Organisation [WHO], 2003). Sadly, the above facts are the overwhelming situations in Rivers State, hence this study. Thus, to advance evidences on which this study stands, related studies were reviewed on Environmental Crude Oil Pollution and its Rising Levels of Socioeconomic alongside Health Vulnerabilities, the World Over.

\subsection{Environmental Crude Oil Pollution and its Rising Levels of Socioeconomic Vulnerabilities among Peoples, the World Over}

Borasin, Foster, Tobarteh, Link, Miranda, Pomeranse, Rabke-Verani, Reyes, Selber, Sodha and Somaia (2002) argue that onshore drilling poses risks for livestock. Crude oil and salt water spills, common occurrences around production sites, and pipeline breaks can all expose livestock to crude oil or refined petroleum hydrocarbon (Borasin, et al, 2002). What is worse is the fact that ingestion of petroleum hydrocarbons by livestock can cause sudden death (Edwards, 1989). Again, ingestion of petroleum hydrocarbons can also lead to devastating effects on aquatic lives, which may in turn adversely affect the means of livelihood of people in such areas of crude oil exploration and its spills. In this circumstance, however, Qurban, Joydas, Manikandan, Krishnakuma and Wafar (2012) in their book entitledOil-related Activities and Environmental Concerns in the Gulf explain that spills and leakages have adverse effects:

- As oil floats on top of water, less light penetrates limiting the photosynthesis of marine plants and phytoplankton.

- Oil destroys the insulating ability of fur-bearing mammals such as sea otters and water-repelling abilities of bird's feathers-causing mortality.

- Birds and marine mammals ingest oil when they clean themselves, causing them to be killed or injured.

In another scenario, Hussain and Khalil (2013) in their study entitledEnvironment and Sustainable Development in the Kingdom of Saudi Arabia: Current Status and Future Strategy also argue that damage to the marine ecosystem adversely affects the area's general attraction to tourists and it also has an effect on the fishing industry. Thus, the resultant adverse effects of the foregoing study may include that the inhabitants who engage in tourism business will find it difficult to sustain their livelihoods; hence the damage of marine-based eco-tourism. Apart from this, the inhabitants along the marine ecosystem areas in Saudi Arabia will begin to loose their economic activities (specifically fishing and trading activities), due to the oil pollution damage on aquatic life and economic trees.

Similarly, in August 1983 Oshika village in Rivers State witnessed a spill of 5,000 barrels of oil from Ebocha-Brass (Ogada-Brass24) pipeline which flooded the lake and swamp forest, the area which had previously experienced an oil spill of smaller quantity; 500 barrels in September 1979 with mortality in crabs, fish and shrip (Kadafa, 2012). In the circumstances of these facts, large areas of mangrove forest have been destroyed over a wide area affecting terrestrial and marine resources (Kadafa, 2012). This is an obvious situation among the coastal area residents, where some past crude oil spills have necessitated the complete relocation of some communities, lost of forest and agricultural land, destruction of fishing grounds and reduction of fish population, which is the major source of income of the Niger Delta people (Tolulope, 2004). Additionally, Oriji (2017:58) posits that:

The pollutants arising from environmental pollution have great impacts on the socioeconomic life of the people, such that livestock, aquatic life and crops on which they depend are decimated. In this regard, farmers suffer from decline in income and opportunity to strive in their occupation (farming). Thus, the resultant effects on families are that there will be increase in school drop-outs and starvation among children of farmers whose means of livelihood is affected by environmental pollutants. In these circumstances, the drop-out students will become 'endangered species' and if not well managed may take to crimes. This is the situation in most Niger Delta communities where those affected by industrial pollutants cannot fish or do small-scale crop farming on available land; and thus are left with no other choice than kidnapping. 
Sequel to the above facts, the people are complaining about the loss of farmlands due to the presence of exploration and production of activities of petroleum in Ogoni land (Brown and Tari, 2015); and that the consequences of same have led to a change in the farming calendar with attendant poor soil fertility and decline in crop yield. Apart from the environmental hazard on the farm land, pollution of rivers through oil spillage could result in massive extermination of fishes and thereby threaten the social and economic life of communities whose livelihood depends on the contaminated water (Iwejingi, 2013). Also, arable farmlands have been lost to oil pollution as a sizable farmland in the Niger Delta region has been rendered barren due to oil spillage and leakages (Elis, 1994).

\subsection{Environmental Crude Oil Pollution and its Rising Levels of Health Vulnerabilities among Peoples, the World Over}

Well-being of every human is important for his or her healthy living in human environment. However, it is only when such human environment is polluted that humans are faced with health challenges, especially when such pollution was associated with crude oil spills. Taking from this view, Hurting and San Sebastian (2004) in their study entitled Incidence of Childhood Leukemia and Oil Exploration in the Amazon Basin of Ecuador found that there is a relationship between childhood leukemia incidence and living in the proximity of oil fields in Ecuadorian Amazon. In this circumstance, a public health crisis of immense proportions grips the Ecuadorian Amazon, hence the root cause of which is massive contamination from 40 years of oil operations (Amazon Watch, 2017). The unfortunate scenario of the above fact is that Texaco dumped 18 billion gallons of toxic wastewater directly into the region's rivers and streams depended upon for drinking, cooking, bathing and fishing (Amazon Watch, 2017). Thus, the adverse effect is that the contamination of water essential for daily activities of tens of thousands of people has resulted in an epidemic of cancer, miscarriages, birth defects, and other ailments (Amazon Watch, 2017).

Similarly, it is worthy to note that:

Iranians inhale a cocktail of rubber particles, asbestos, sulphur dioxide, nitrogen oxide, carbon monoxide, and partially burnt remnants of hydrocarbons. Not surprisingly, cancer and respiratory illnesses- the second and third highest causes of death in Iran- are on the rise. Nearly 70,000 people are diagnosed with cancer each year, a number that is likely to increase by $90 \%$ by 2020 , according to the Cancer Research Centre of Iran (The Guardian, 2014:2).

In line with the Guardian (2014), the damage to health can arise from both short-term (a few hours or days) and long-term (over months or years) exposure to air pollution (International Energy Agency [IEA], 2016). Worse still, IEA (2016) further explains that air pollution can also contribute to low birth weight, tuberculosis, cataracts and throat cancer, while ozone, nitrogen dioxide and sulfur dioxide are linked to asthma, bronchial disease, reduced lung function and lung disease. In consonance with IEA (2016), Mosteller (2016:1) explain that:

More than half of South Korea's citizens regularly breathe dangerously polluted air, producing serious health effects for the highly urbanized nation in 2013, more than 20,000 premature deaths were blamed on the country's foul air. On a typical day, 25 million South Koreans inhale unsafe amount of microscopic particles of various sizes (P.M2.5, PM10 and others). In April of the above year, the nation suffered through pernicious levels of PM2.5 half of all days. These particles get lodged in people's lungs and other cardiovascular tissues, enter their blood streams, and over time they can lead to respiratory infections, heat disease, lung disease, and cancer.

Consequently, during the environmental pollution cleanup in South Korea, Ha, Kwon, Cheong, Lim, Yoo, Kim, Park, Lee and Chung (2012) report that volunteers participated for longer period of cleanup work suffered from physical symptoms including visual disturbance, nasal and bronchus irritation, headaches, heart palpitations, fatigue and fever, memory and cognitive disturbance, and abdominal pain. Altogether, these results suggested that various acute health problems of cleanup participants and residents were associated with crude oil exposure in Taean area after the Hebei Spirit Oil Spill (HSOS) (Hong, Khim, Ryu, Kang, Shim and Yim, 2014).

Considering the impacts of crude oil spills on human health in Asia, Niger Delta region of Nigeria 
faces more unprecedented devastation of same on its people's health. For instance, residents in the region find that exploitation of crude oil in their communities has not only contributed to inter-ethnic conflict, but it has also degraded their environment, worsened their health and reduce their attempts at improving their quality of life (Ibeanu, 2000; Adeola, 2000; Abdulkareem and Odigure, 2006). In concordance with the foregoing adverse effects of environmental pollution, it is worthy to note that particulate matter, $\mathrm{SO}_{\mathrm{x}}$ and $\mathrm{NO}_{\mathrm{x}}$ emissions are known to contribute to aggravated asthma, coughing, painful breathing, chronic bronchitis, decreased lung function and premature death (Environmental Rights Action [ERA], 2008; Ndubuisi and Asia, 2007). Apart from this evidence, Owate, Nte and Nna (2005) in their book entitled Energy Resources and Environmental Crises explain that impact of air pollutant can cause respiratory related diseases like bronchitis and asthma.

Undoubtedly, Ismail and Umuokoro (2012) also explain that local people in the Niger Delta region complain of respiratory problems such as asthma and bronchitis, premature deaths, cancer and skin rashes. Regretfully, information from World Bank indicated that on a yearly basis, particulate matter emission from gas flaring in Bayelsa alone would cause 49 premature deaths, 4960 respiratory illness among children and 120 asthma attacks (Collins and Oshodi, 2010). In concordance with the above facts, Ajugwo (2013) also reports that pollutants emitted by gas flaring are associated with a variety of adverse health impacts, including cancer, neurological, reproductive, hematological and developmental effects, deformities like congenital cleft palate in children, lung damage and skin problems.

What is worse is the fact that some of these pollutants that mostly affect the health of people adversely, are surphus oxide, surphuric acid, nitric oxide, carbon monoxide and smoke of suspended particulates; and they are found in industrialized countries as well as oil producing countries of the 'Third World' (Oriji, 2014). In addition, Harmon (2010:2) also delineates that:

Crude oil is made up of thousands of chemical compounds. Some of the lighter ones, including benzene, are known as volatile organic compounds (VOCs) and tend to evaporate soon after they reach the water's surface. These chemicals can cause respiratory problems as well as temporary central nervous system troubles. And some VOCs have been linked to cancers at high exposure levels.

\section{Statement Of The Problem}

In the early 1950s, there were no challenges of crude oil pollution; hence crude oil (black gold) has not been discovered for exploration and exploitation in Nigeria. But in 1956 when crude oil was discovered in Oloibiri, and subsequently was produced in high quantities for export in 1958, Nigerians started experiencing environmental pollution in the Niger Delta region. As exploration of crude oil continued in a crescendo for export to the West, not much was done by the Federal Government of Nigeria (FGoN) and multinational companies to address environmental crude oil pollution in the region. In these ugly circumstances, most Nigerians were exposed to socio-economic and health challenges, due to incessant crude oil pollution in the region.

Thus, to come out of "this maze of crude oil pollution", attempts were made by FGoN in 1960s, 1970s, 1980s and 1990s to develop policies that will help guide crude oil exploration with minimal spills in the region. Surprisingly, these policies were handled by FGoN and multination companies with "kid glove"; hence the continuous crude oil spills in the region. Thus, the resultant effect of poor policies implementation against crude pollution was high level of environmental pollutants in the region between 2000s and 2017. Thus, with regard to the high level of crude oil pollutants in the Niger Delta region, the National Assembly of Nigeria made laws to end the crude oil pollution in the region. Again, the implementation of these laws met its waterloo; hence the lackadaisical attitudes of FGoN to enforce same in Nigeria.

Drawing from the above situation, researches were conducted to support the FGoN to end, 'the unending crude oil pollution' that has affected the economy and health of the people adversely in the region. But all these researches did not address the rising levels of environmental crude oil pollution on the people, with reference to their socioeconomic/health vulnerabilities in the Niger Delta States, specifically in Rivers State. In order to address this lacuna, this study was carried out to investigate the Environmental Crude Oil Pollution and the Rising Levels of Socioeconomic/Health Vulnerabilities Among the Rural People in Rivers State, Nigeria. 


\section{OBJECTIVES OF THE STUDY}

The following objectives are posited for the study:

i. To investigate the correlation between environmental crude oil pollution and its rising level of socioeconomic vulnerability among the rural people of Rivers State.

ii. To examine the correlation between environmental crude oil pollution and its rising level of health vulnerability among the rural people of Rivers State.

\section{HYPOTHESES OF THE STUDY}

The following null hypotheses are formulated for the study:

i. There is no significant correlation between environmental crude oil pollution and its rising level of socioeconomic vulnerability among the rural people of Rivers State.

ii. There is no significant correlation between environmental crude oil pollution and its rising level of health vulnerability among rural people of Rivers State.

\section{RESEARCH METHODS}

Survey design is used for the study. The population of the study is Rivers State of Nigeria. It covers all rural people in Rivers State. A sample of 300 rural respondents is selected for the study. The selection is done by the use of simple random sampling and accidental sampling techniques. Thus, simple random sampling technique is used to select one Local Government Area (LGA) in Rivers State. In doing so, the $23 \mathrm{LGAs}$ were written on papers and wrapped by the researcher. These were then put in a basket for picking. One research assistant was called to mix up the wrapped papers of the 23 LGAs of Rivers State for the purpose of picking one LGA. Through this process, the research assistant called upon picked the GokanaLGA for the study. Furthermore, respondents were accidentally (reached by chance of who were met) selected in the GokanaLGA using accidental sampling technique. In realizing this, 300 rural people (respondents) were selected in the GokanaLGA. The instrument used for data collection is the questionnaire. It is structured into Section A: Biographical data with multiple questions (items) based on marital status, occupational status, type of education acquired, level of income for livelihood and ill health status at the time of this study. Section B: Field responses based on the hypotheses are used in categorized items of 'high', 'average' and 'low' socioeconomic and health vulnerabilities among the rural people, with special reference to environmental crude oil pollution in the study area.

Face validity of the instrument is established by professionals in the Department of Sociology, Faculty of Social Sciences, University of Port Harcourt, Choba. Apart from this, test-retest method of reliability is used to ascertain the reliability value of 0.82 Correlation Co-efficient for the study. The researcher administered the copies of the questionnaire with the help of his paid personnel; and they collected same immediately the responses were completed by the respondents. The statistical methods used for the study are percentage, a frequency table, and a bar-graph as well as chi-square $\left(\chi^{2}\right)$. Percentage and a bar-graph are used to analyse biographical data of respondents' results as presented in a frequency table and a bar-graph for the study. In addition, $\chi^{2}$ is used to analyse the tested hypotheses from which findings are drawn for the study.

\section{RESUlts}

Table1. Biographic Data of Respondents

\begin{tabular}{|l|l|l|}
\hline Biographic Characteristics & No. of Respondents & Percentages \\
\hline Marital Status & & \\
\hline Married & 264 & 88 \\
\hline Single & 36 & 12 \\
\hline Occupation Status & & \\
\hline Crop farmers & 120 & 40 \\
\hline Fisher men and women & 120 & 40 \\
\hline Traders & 30 & 10 \\
\hline Civil Servants & 15 & 5 \\
\hline Others in other occupations & 15 & 5 \\
\hline
\end{tabular}


Environmental Crude Oil Pollution and its Rising Levels of Socioeconomic/Health Vulnerabilities among the Rural People in Rivers State, Nigeria

\begin{tabular}{|l|l|l|}
\hline $\begin{array}{l}\text { Type of Education Acquired at } \\
\text { the Time of the Study }\end{array}$ & \\
\hline Non-formal education & 264 & 88 \\
\hline Formal education for & 36 & 12 \\
\hline $\begin{array}{l}\text { Level of Income earned } \\
\text { Livelihood }\end{array}$ & 180 & \\
\hline Low income & 90 & 60 \\
\hline Moderate income & 30 & 30 \\
\hline High income & & 10 \\
\hline Ill Health Status & 210 & 70 \\
\hline Very sick & 90 & 30 \\
\hline Not very sick &
\end{tabular}

Source: Author's Field Survey, 2017

\begin{tabular}{|c|c|c|c|c|c|c|c|c|c|c|c|c|c|c|}
\hline $\begin{array}{r}300 \\
250 \\
200 \\
150 \\
100 \\
50 \\
0\end{array}$ & 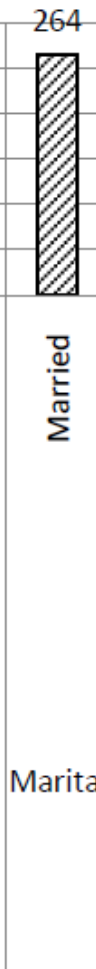 & $\begin{array}{l}36 \\
\mathbb{Z Z} \\
\frac{0}{00} \\
\stackrel{\Xi}{\sim} \\
\text { Status }\end{array}$ & 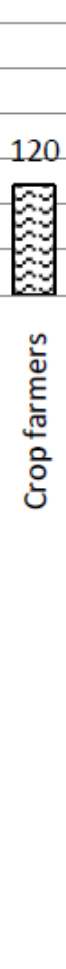 & 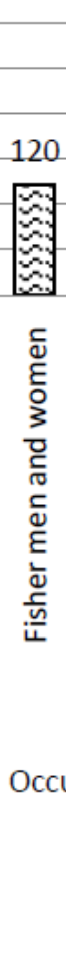 & $\begin{array}{l}30 \\
\text { ख్య } \\
\cong \\
\frac{0}{0} \\
\stackrel{0}{\circ}\end{array}$ & 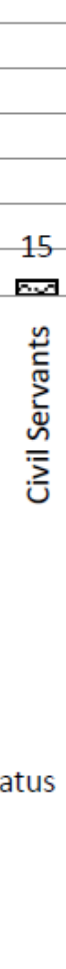 & 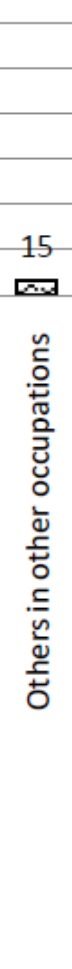 & 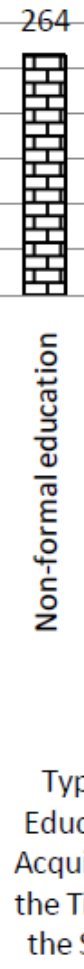 & 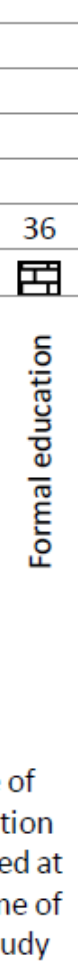 & $\begin{array}{l}180 \\
\equiv \\
\bar{\theta}\end{array}$ & 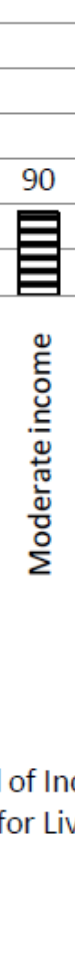 & 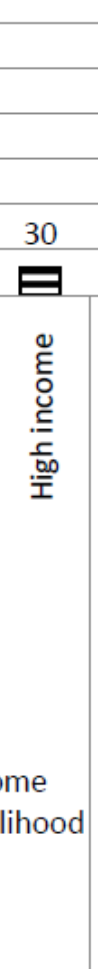 & 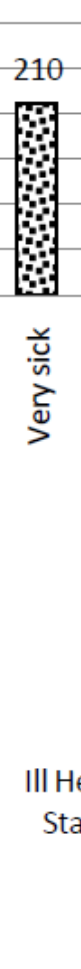 & 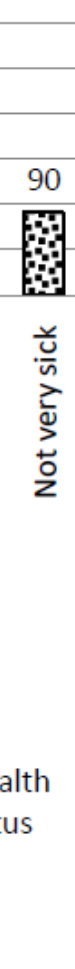 \\
\hline
\end{tabular}

Source: Author's Fieldwork, 2017

The results of marital status indicate that 264 respondents, representing $88 \%$ were married rural people, while 36(12\%) were single rural people. Based on the aforementioned data, it is evident that more married rural people were used in the study area than single rural people due to their incessant complaints of environmental crude oil pollution impacts on them. This is so because the married people form family units which also consist of single people. For occupational status, the results depict that 120 respondents, representing $40 \%$ wee crop farmers, $120(40 \%)$ were fisher men and women, $30(10 \%)$ were traders, $15(5 \%)$ were civil servants, while $15(5 \%)$ were others in different occupations not mentioned. Taking from the above data, it is crystal clear that those whose occupations are farming and fishing are those who are mostly engrossed in socioeconomic and health vulnerabilities caused by environmental crude oil pollution in their communities. However, this was not the case with the traders, civil servants and others in other occupations because they are not in direct contact of environmental crude oil spills like the crop farmers, and fisher men and women in their communities.

In addition, for the type of education acquired at the time of the study, the results delineate that 264 respondents, representing $88 \%$ had non-formal education, and therefore, had no in-depth awareness of high levels of socioeconomic/health vulnerabilities resulting from environmental crude oil pollution, while 36(12\%) had in-depth awareness of it; hence their precautionary measures of the impacts of 
Environmental Crude Oil Pollution and its Rising Levels of Socioeconomic/Health Vulnerabilities among the Rural People in Rivers State, Nigeria

same on them. Thus, the resultant effect of the crude oil pollutants on the former respondents, is the fact that they are 'worst hit' than the later respondents, due to their 'half glass of knowledge' of same. Consequently, for the level of income earned for livelihood during the incidences of environmental crude oil pollution, 180 respondents, representing $40 \%$ had low incomes from their occupations, due to high level of crude oil pollutants, 90(30\%) had moderate incomes, while 30(10\%) had high incomes. The fact of the foregoing data is that those who had both moderate and high incomes did so, because they were not 'worst hit' by the environmental crude oil pollutants. The reason for this is these groups of respondents were doing businesses 'to and fro' the risk and unrisk areas of crude oil pollution in their communities. Finally, for ill health status, the results prove that 210 respondents, representing $70 \%$ were very sick because of high level of environmental crude oil pollutants in their communities, while $90(30 \%)$ were not very sick, due to minimal impacts of same on their health.

Table2. Analysis of the Correlation between Environmental Crude Oil Pollution and its Rising Level of Socioeconomic Vulnerability among the Rural People of Rivers State

\begin{tabular}{|l|l|l|l|c|}
\hline \multirow{2}{*}{ Respondents } & \multicolumn{2}{|c|}{ Responses } & \multirow{2}{*}{ Total } \\
\cline { 2 - 4 } & $\begin{array}{l}\text { High Rising Level of } \\
\text { Socioeconomic } \\
\text { Vulnerability }\end{array}$ & $\begin{array}{l}\text { Average Rising Level of } \\
\text { Socioeconomic } \\
\text { Vulnerability }\end{array}$ & $\begin{array}{l}\text { Low Rising Level of } \\
\text { Socioeconomic } \\
\text { Vulnerability }\end{array}$ & 40(36.66) \\
\hline $\begin{array}{l}\text { Non-formally } \\
\begin{array}{l}\text { Educated Rural } \\
\text { People }\end{array}\end{array}$ & $80(93.33)$ & $80(70)$ & $15(18.33)$ & 100 \\
\hline $\begin{array}{l}\text { Formally Educated } \\
\text { Rural People }\end{array}$ & $60(46.66)$ & $25(35)$ & $\mathbf{5 5}$ & $\mathbf{3 0 0}$ \\
\hline Total & $\mathbf{1 4 0}$ & $\mathbf{1 0 5}$ & & \\
\hline
\end{tabular}

Source: Author's Fieldwork, 2017

Table3. Chi-square $\left(\chi^{2}\right)$ In-depth Computation of the Analysis of the Correlation between Environmental Crude Oil Pollution and its Rising Level of Socioeconomic Vulnerability Amongthe Rural People of Rivers State

\begin{tabular}{|l|c|c|c|c|c|}
\hline $\begin{array}{l}\text { Serial } \\
\text { Number }\end{array}$ & $\begin{array}{c}\text { Observed } \\
\text { Frequency (OF) }\end{array}$ & $\begin{array}{c}\text { Expected } \\
\text { Frequency (EF) }\end{array}$ & OF-EF & $($ OF-EF) & $\frac{(O F-E F)^{2}}{E F}$ \\
\hline 1 & 80 & 93.33 & -13.33 & 177.6889 & 1.90 \\
2 & 80 & 70 & 10 & 100 & 1.42 \\
3 & 40 & 36.66 & 3.34 & 11.1556 & 0.30 \\
4 & 60 & 36.66 & 13.34 & 177.9556 & 3.81 \\
5 & 25 & 18.33 & -10 & 100 & 3.85 \\
6 & 15 & & & 11.0889 & 0.60 \\
\hline Total & & & & & $\mathbf{1 1 . 8 8}$ \\
\hline
\end{tabular}

Calculated $\chi^{2}=11.88>$ table value $=5.99 ;$ level of significance $=0.05 ;$ degree of freedom $(d f)=2$

Source: Author's Fieldwork, 2017

The result of the analysis presented in Tables 2 and 3 shows that the calculated $\chi^{2}$ value of 11.88 is higher than the table value of 5.99 at 0.05 level of significance withdf of 2 . Taking from this fact, the result of the analysis is said to be significant, hence the calculated value is higher than the table value. With this result, the null hypothesis is rejected. In line with this fact, it means that there is a significant correlation between environmental crude oil pollution and its rising level of socioeconomic vulnerability among the rural people in the study area.

Table4. Analysis of the Correlation between Environmental Crude Oil Pollution and its Rising Level of Health Vulnerability among the Rural People of Rivers State

\begin{tabular}{|l|c|c|c|c|}
\hline \multirow{2}{*}{ Respondents } & \multicolumn{3}{|c|}{ Responses } & Total \\
\cline { 2 - 4 } & $\begin{array}{c}\text { High Rising Level of } \\
\text { Health Vulnerability }\end{array}$ & $\begin{array}{c}\text { Average Rising Level } \\
\text { of Health Vulnerability }\end{array}$ & $\begin{array}{c}\text { Low Rising Level of } \\
\text { Health Vulnerability }\end{array}$ & \\
\hline $\begin{array}{l}\text { Non-formally Educated } \\
\text { Rural People }\end{array}$ & $95(106.66)$ & $65(56.66)$ & $40(36.66)$ & 200 \\
\hline $\begin{array}{l}\text { Formally Educated } \\
\text { Rural People }\end{array}$ & $65(53.33)$ & $20(28.33)$ & $15(18.33)$ & 100 \\
\hline Total & $\mathbf{1 6 0}$ & $\mathbf{8 5}$ & $\mathbf{5 5}$ & $\mathbf{3 0 0}$ \\
\hline
\end{tabular}

Source: Author's Fieldwork, 2017 
Environmental Crude Oil Pollution and its Rising Levels of Socioeconomic/Health Vulnerabilities among the Rural People in Rivers State, Nigeria

Table5. $\chi^{2}$ In-depth Computation of the Analysis of the Correlation between Environmental Crude Oil Pollution and its Rising Level of Health Vulnerability among the Rural People of Rivers State

\begin{tabular}{|l|c|c|c|c|c|}
\hline $\begin{array}{l}\text { Serial } \\
\text { Number }\end{array}$ & $\begin{array}{c}\text { Observed } \\
\text { Frequency (OF) }\end{array}$ & $\begin{array}{c}\text { Expected } \\
\text { Frequency (EF) }\end{array}$ & OF-EF & $(\text { OF-EF })^{\mathbf{2}}$ & $\frac{(O F-E F)^{2}}{E F}$ \\
\hline 1 & 95 & 106.66 & -11.66 & 135.9556 & 1.27 \\
2 & 65 & 56.66 & 8.34 & 69.5556 & 1.22 \\
3 & 46.66 & 3.34 & 11.1556 & 0.30 \\
4 & 65 & 53.33 & 11.67 & 136.1889 & 2.55 \\
5 & 20 & 28.33 & -8.33 & 69.3889 & 2.44 \\
6 & 15 & 18.33 & -3.33 & 11.0889 & 0.60 \\
\hline Total & & & & & $\mathbf{8 . 3 8}$ \\
\hline
\end{tabular}

Calculated $\chi^{2}=8.38>$ table value $=5.99 ;$ level of significance $=0.05 ; d f=2$

Source: Author's Fieldwork, 2017

The result of the analysis presented in Tables 4 and 5 depicts that calculated $\chi^{2}$ value of 8.38 is higher than the table value of 5.99 at 0.05 level of significance with $\mathrm{df}$ of 2 . In consonance with the above facts, the result of the analysis is said to be significant, hence the calculated value is higher than the table value. In congruence with the above result, the null hypothesis is rejected. With regard to the foregoing analysis, it means that there is a significant correlation between environmental crude oil pollution and its rising level of health vulnerability among the rural people in the study area.

\section{Discussion OF THE FINDINGS}

The result of the first hypothesis depicts that there is significant correlation between environmental crude oil pollution and its rising level of socioeconomic vulnerability among the rural people of Rivers State in Nigeria. This result is in line with Kadafa (2012) who explains that in August 1983, Oshika village in Rivers State witnessed a spill of 5,000 barrels of oil from Ebocha-Brass (OgadaBrass 24) pipeline which flooded the lake and swamp forest, the area which had previously experienced an oil spill of smaller quantity; 500 barrels in September 1979 with mortality in crabs, fish and shrimp. Besides, the result of the first hypothesis is also supported by Oriji (2017:58) who posits that:

The pollutants arising from environmental pollution have great impacts on the socioeconomic life of the people, such that livestock, aquatic life and crops on which they depend are decimated. In this regard, farmers suffer from decline in income and opportunity to strive in their occupation (farming). Thus, the resultant effects on families are that there will be increase in school drop-outs and starvation among children of farmers whose means of livelihood is affected by environmental pollutants. In these circumstances, the drop-out students will become 'endangered species' and if not well managed may take to crimes....

Similarly, the result of the second hypothesis proves that there is a significant correlation between environmental crude oil pollution and its rising level of health vulnerability among the rural people of Rivers State in Nigeria. The result of the second hypothesis is in tandem with Hurtig and San Sebastian (2004) who in their study entitled Incidence of Childhood Leukema and Oil Exploration in the Amazon Basin of Ecuador found that there is a relationship between childhood leukemia incidence and living in the proximity of oil fields in Ecuadorian Amazon. Also in support of the result of second hypothesis, the damage to health can arise from both short-term (a few hours or days) and long-term (over months or years) exposure to air pollution (IEA, 2016). Worse still, the IEA (2016) further explains that air pollution can also contribute to low birth weight, tuberculosis, cataracts and throat cancer, while ozone, nitrogen dioxide and sulfur dioxide are linked to asthma, bronchial disease, reduced lung function and lung disease.

\section{CONCLUSION}

In line with the in-depth findings of the study, it is obvious that there are links between environmental crude oil pollution and its rising levels of socioeconomic/health vulnerabilities among the rural people of Rivers State. These findings are undoubtedly true because the incessant environmental crude oil pollution is today a resultant decline in means of livelihood, which in turn is associated with the rising 
level of crimes in the study area. Again, with regard to the above findings, environmental crude oil pollution is also responsible for the rising level of illnesses/diseases the rural people of Rivers State are battling with today. Thus, to come out of this startling environmental crude oil pollution with its adverse effects on the means of livelihood and health of the rural people permanently as well as sustain same, the study suggests precise researches on the need for implementation of environmental crude oil pollution laws for sustainable socioeconomic development, as well as the relationship between safe crude oil exploration and sustainable well-being of people in rural communities of Rivers State, and indeed in other crude oil producing states of Nigeria.

\section{RECOMMENDATIONS}

i. The federal government in conjunction with the state government should ensure that they work with multinational companies to cleanup crude oil spills in the rural areas of the state, based on the international best practices, alongside adhere to the domesticated crude oil pollution laws in Nigeria.

ii. The federal government in conjunction with the state government should establish a monitoring team through the Act of National Assembly, for which its mandate will be to quarterly monitor the multinational crude oil and gas exploration companies on their level of compliance with the crude oil pollution laws, and report those who defaulted same to FGoN for stringent sanctions.

iii. The federal government in conjunction with the state government should, through their traditional and social media outlets inform, educate and communicate with the rural people on the danger of environmental crude oil pollutants on them, and why they should move away from such polluted risk-areas to safe areas.

iv. The federal government in conjunction with the state government should establish out-reach programme agency in Ministry of Environment and Water Resources with the aim of mandating it with the responsibility to reach the rural people who are suffering from socioeconomic and health challenges, caused by crude oil pollutants. In carrying out the above responsibility, the personnel in the agency should go to the oil rich communities to teach the rural people the fishing and farming techniques that will help them sustain their livelihood besides treating those (the sick) who are adversely affected with crude oil pollution related diseases in the study area.

\section{REFERENCES}

[1] Abdulkareem, A.S. and Odigare, J.O. (2006). Deterministic Model for Noise Dispersion from Gas Flaring: a Case Study of Niger Delta Area of Nigeria. Chemical and Biochemical Engineering Quarterly. 20(2): 157-164.

[2] Adeola, F. (2000). Cross-National Environmental Injustices and Human Rights Abuse: the States, MNCs, and Repression of Minority Groups in the World System. Human Ecology Review. 8(1): 39-59.

[3] Ajugwo, A.O. (2013). Native Effects of Gas Flaring: The Nigerian Experience. Journal of Environmental Pollution and Human Health. 1(1): 6-8.

[4] Amazon Watch (2017). Chevron's Chernobyl in the Amazon. Retrieved from http://amazonwatch.org/ work/chevron/07/09/2017.

[5] Barasin, S. et al (2002).A Life Cycle Analysis of its Health and Environmental Impacts (Edited by Paul R. Epstein and Jesse Selber). Boston. The Centre for Health and the Global Environmental Harvard medical School: 11.

[6] Brown, I. and Tari, E. (2015).An Evaluation of the Effects of Petroleum Exploration and Production Activities on the Social Environment in Ogoni Land, Nigeria. International Journal of Scientific and Technology Research. Vol. 4, Issue 04: 278.

[7] Collins, C. and Oshodi, O. (2010). Improper Abandonment of Oil. Retrieved from http://www.nigeriansinamerica.com/improper-abandonement-of-oil/05/09/2017.

[8] Edwards, W.C. (1989). Toxicology of Oil Field Wastes Hazards to Livestock Association with the Petroleum Industry. Veterinary Clinics of North America: food Animal Practice. 5(2): 363-374.

[9] Elis, G. (1994). Shell in Nigeria. What are the Issues. Retrieved from http://www.essentialaction.org/ shell/issues.htm/06/08/2017.

[10] EPC Centres (2017).Oil Spill Pollution. Retrieved from http://www.environmentalpollutioncentres.org/oilspill/10/09/2017.

[11] ERA (2008). Toxic Flares: harmful Gas Flaring in Nigeria. Environmental Impact Issues: 1-8. 
[12] Ha, M. et al (2012). Urinary Metabolites before and after Cleanup and Subjective Symptoms in Volunteer Participants in Cleanup of the Hebei Spirit Oil Spill. Science Total Environ. 429: 167-173.

[13] Harmon, K. (2010). Oil Spill's Human Health Impacts Might Extend into the Future. Retrieved from https://blogs.scientificamerican.com/observations/oil-spills-human-health-impacts-might-extend-into-thefuture/05/09/2017.

[14] Hong, S. et al (2014).Environmental and Ecological Effects and Recoveries after Five Years of the Hebei Spirit Oil Spill, Taean, Korea. Ocean and Coastal management. 102: 522-532.

[15] Hurtig, A. and San Sebastian, M. (2004).Incidence of Childhood Leukemia and Oil Exploration in the Amazon, Basin of Ecuador. International Journal of Occupational and Environmental Health: 245-250.

[16] Husain, T. and Khalil, A.A. (2013). Environmental and Sustainable Development in the Kingdom of Saudi Arabia: current Status and Future Strategy. Journal of Sustainable Development. Canada Centre of Science and Education. Vol. 6. No. 12: 25.

[17] Ibeanu, O. (2000). Oiling the Friction: Environmental Conflict Management in the Niger Delta, Nigeria. Change and Security Project Report. 6: 19-32.

[18] IEA (201). Energy and Air Pollution: World Energy Outlook Special Report. Retrieved from https:www.iea.org/publications/freepublications/publication/WorldEnergyOutlookSpecialReport2016Ener gyandAirPollution.pdf/09/2017.

[19] Ismail, O.S. and Umuokoro, G.E. (2012).Global Impact of Gas Flaring Energy and Power Engineering.

[20] Iwejingi, S.F. (2013). Socio-economic Problems of Oil Exploration and Exploitation in Nigeria's Niger Delta. Journal of Energy Technologies and Policy. Vol. 3. No. 1: 78.

[21] Kadafa, A.A. (2012). Environmental Impacts of Oil Exploration and Exploitation in the Niger Delta of Nigeria. Global Journal of Science Frontier Research Environmental and Earth Sciences. Vol. 12. Issue 3. Version 1.0: 19.

[22] Mosteller, D. (2016). Air Pollution's Hazy Future in South Korea. Retrieved from datadriven.yale.edu/airquality-2/air-pollutions-hazy-future-in-south-korea-2/10/09/2017.

[23] Ndubuisi, O.L. and Asia, I.O. (2007).Environmental Pollution in Oil Producing Areas of the Niger Delta Basin, Nigeria. Empirical Assessment of Trends and People's Perception. Environmental Research Journal. 9(1-4): 18-26.

[24] Ordinioha, B. and Brisibe, S. (2013). The Human Health Implications of Crude Oil Spills in the Niger Delta, Nigeria: an Interpretation of Published Studies. Nigerian Medical Journal. 54(1): 10-16.

[25] Oriji, C.C. (2014). Relationship between Air Pollution and Ill Health of People in Rivers State, Nigeria. Social Spectrum: a Journal of South-South Chapter of the Social Studies and Civic Educators Association of Nigeria (SOSCEAN). 11(8): 36.

[26] Oriji, C.C. (2017). Understanding Environmental Sociology for Socio-economic Development in Nigeria. Port Harcourt. University of Port Harcourt Press. 58.

[27] Owate, I.O., Nte, F.U. and Nna, J. (2005).Energy Researches and Environmental Crises. Port Harcourt. Peal Publishers: 131-260.

[28] Qurban, M. et al (2012).Oil-related Activities and Environmental Concerns in the Gulf. Retrieved from https://www.jccp.org.jp/international/conference/docs/hpe794a8-drmohammad-quarban-kfupmabstract1.pdf/15/09/2017.

[29] The Guardian (2014). Every Breath You Take: the Environmental Consequences of Iran Sanctions. Retrieved from https://www.theguardian.com/world/iran-blog/2014/nov/21/iran-environmentalconsequences-of-sanctions/08/09/2017.

[30] Tolulope, A.O. (2004). Oil Exploration and Environmental Degradation: the Nigerian Experience. International Society for Environmental Information Science. 2: 387-393.

[31] WHO (2003).The World Health Report 2002: reducing Risks, Promoting Healthy Life. Geneva. WHO: 1 71.

Citation: Oriji, Christian Chigozi. "Environmental Crude Oil Pollution and its Rising Levels of Socioeconomic/Health Vulnerabilities among the Rural People in Rivers State, Nigeria." International Journal of Humanities Social Sciences and Education (IJHSSE), vol 5, no. 8, 2018, pp. 82-91 doi: http://dx.doi.org/10.20431/2349-0381.0508010.

Copyright: () 2018 Authors. This is an open-access article distributed under the terms of the Creative Commons Attribution License, which permits unrestricted use, distribution, and reproduction in any medium, provided the original author and source are credited. 